\title{
ASSESSMENT OF CD, CU, ZN AND NI BIOACCUMULATION AND METALLOTHIONEIN CONCENTRATIONS IN Mytilus galloprovincialis IN SIDI IFNI COAST (SOUTH ATLANTIC OF MOROCCO)
}

\author{
Mohamad Abbassi ${ }^{12^{2 *}}$, Leila ${ }^{\text {Aboudlou1 }}$, Imane Charioui ${ }^{1}$, Maryem Nadir ${ }^{1}$, Mustapha Agnaou $^{1}$, Omar Achahour $^{3}$, \\ Samir Bari ${ }^{1}$, Jamel Jebali ${ }^{4}$, Bah Hamoudi ${ }^{1,5}$, Mohamed Bani ${ }^{4}$ and Abderrazak Kaaya ${ }^{1}$ \\ ${ }^{1}$ BioEnvironment, Health and Bioresources Team, Faculty of Sciences, University Ibn Zohr, Agadir, Morocco \\ ${ }^{2}$ Suprior Institute of Maritime Fishing, Agadir, Morocco \\ ${ }^{3}$ Laboratory of Materials and Renewable Energy, Faculty of Sciences, University Ibn Zohr Agadir, Morocco \\ ${ }^{4}$ Laboratory of Biochemistry and Environmental Toxicology, Higher Institute of Agronomy, ISA, 4042, \\ ChottMariem, Sousse, Tunisia \\ ${ }^{5}$ Marine and Coastal Environment Study Laboratory, Mauritanian Institute for Oceanographic Research and \\ Fisheries, Nouadibou, Mauritania
}

https://doi.org/10.35410/IJAEB.2021.5632

\begin{abstract}
This paper is concerned with the assessment of $\mathrm{Cd}, \mathrm{Cu}, \mathrm{Zn}$ and $\mathrm{Ni}$ bioaccumulation and metallothionein concentrations in Mytilus galloprovincialis infour in four sites representative of Sidi Ifni's coastline (South Atlantic of Morocco):Mirleft site (S1), Cheikh Sidi Ali Ifni (S2), Station of wastewater epuration (STP - S3) andTazrout site (S4).

Compared to the control site (S1), the highest concentrations of are observed in mussels originating at the S2 (in summer, autumn and winter) and in the S3 in the spring. Levels of metallothionein showed like seasonal variations with significant high values at $\mathrm{S} 2$ site.
\end{abstract}

Keywords: Bioaccumulation - Biomarker - Metal - Mettallothionein - Morocco - Mytilus galloprovincialis -Sidi Ifni.

\section{INTRODUCTION}

In recent years, the coasts of the city of Sidi Ifni (Southern Atlantic of Morocco) have known a significant socio-economic development (Fisheries and touristic activities). Although, part of this ecosystem received several types of pollutants which are discharged in the seawater without any treatment. Our previous studies, in which physico-chemical parameters of the coastal waters of the city $\left(\mathrm{T}^{\circ} \mathrm{C}, \mathrm{pH}\right.$, Dissolved $\mathrm{O}_{2}$, Salinity, Conductivity, Turbidity, Salinity, Chlorides, Sulfates, Phosphorus, Ammonia Nitrogen, Nitrate and Nitrite) (Abbassi et al., 2017) and some biomarkers (Acetylcholinesterase, Catalase, Glutathione S-transferase activities and Malondialdehyde level) (Abbassi et $a l ., 2015$ ) revealed a real disturbance of the physical and chemical characteristics of seawater and of marine organisms (Mytilus galloprovincialis) living at the sites receiving domestic and industrial wastewater of this ecosystem

In the present work about metallic pollution, $\mathrm{Cd}, \mathrm{Cu}, \mathrm{Zn}$ and $\mathrm{Ni}$ bioaccumulation and metallothionein (MT) concentrations were evaluated in Mytilus galloprovincialis. Theseenvironmental pollutants are wellknown to their toxicity, persistence in the environment, and bioaccumulative nature (Hazrat etal., 2019). 
Indeed, data about heavy metals in marine organisms from Moroccan coasts were rare and limited to the north Atlantic coasts in Morocco (El Hraiki et al., 1992;Cheggour et al., 1999;Kaimoussi 2001;Kaaya, 2002;Eddaoudi et al., 2014). The accumulation and transformation capabilities of pollutants make these sentinel organisms suitable for marine pollution monitoring (Lower and Kendall, 1990).

Otherwise, this work constituted also a contribution in the assessment of the heavy metal level in the African South-West Moroccan coasts, which were characterized by an important upwelling responsible for the wealth of marine resources.

\section{MATERIALS AND METHODS}

\section{Sampling sites(Figure 1)}

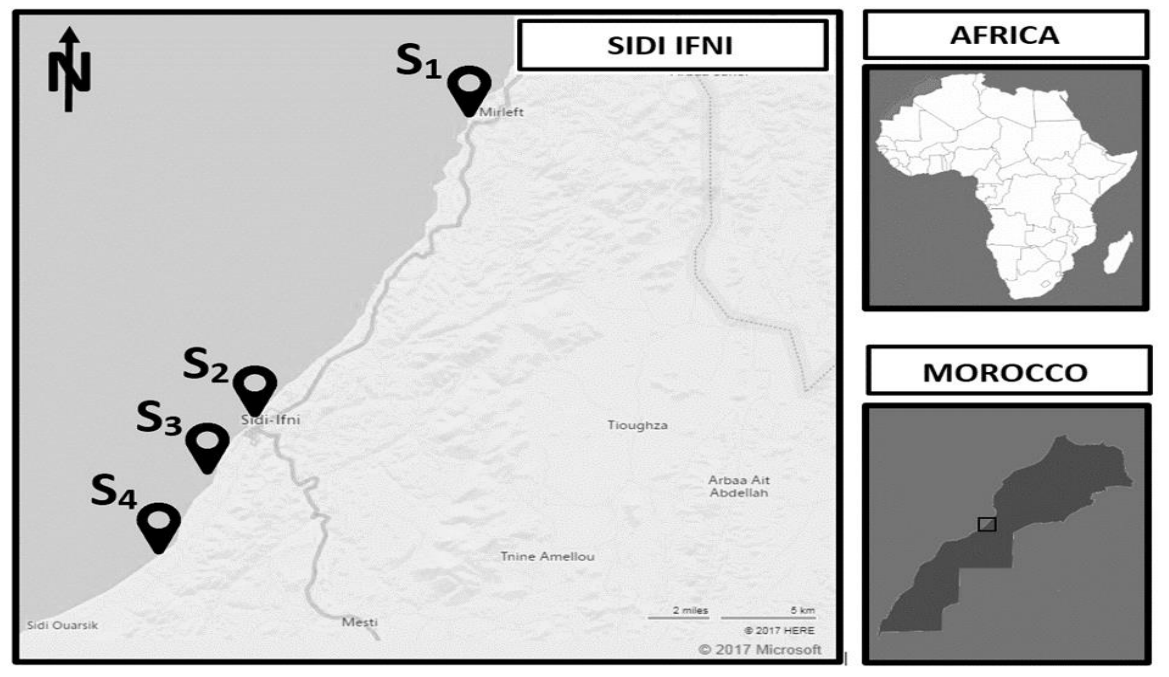

Figure 1: Map of sampling sites in coastline of Sidi Ifni:Mirleft site (MIR - S1),Cheikh Sidi Ali site (CHIKH - S2), Sidi Ifni wastewater treatment plant (STP - S3) and Tazrout site (TZR - S4)

Sampling was conducted in four sites representative of Sidi Ifni's coastline : $i$ ) Mirleft site (S1) (Coordinated : $29^{\circ} 58^{\prime} 41.68^{\prime \prime} \mathrm{N}, 10^{\circ} 07^{\prime} 40.82^{\prime} ' \mathrm{~W}$ ), which is considered as reference site, located at $30 \mathrm{Km}$ to the north of Sidi Ifni, far from any source of pollution, ii) Cheikh Sidi Ali Ifni (S2) (Coordinated : $29^{\circ} 38^{\prime} 70.55^{\prime} \mathrm{N}, 10^{\circ} 17^{\prime} 29.54^{\prime} \mathrm{W}$ ) located at the entrance of Sidi Ifni at the rejection of the Oued Sidi Ifni and receives untreated wastewaters of the city, iii) Station of

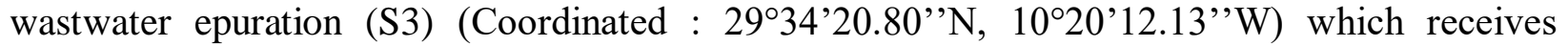
treated wastewaters of a part of Sidi Ifni city and iv) Tazrout site (S4) (Coordinated: 29$\left.17^{\prime} 37.39 " \mathrm{~N}, 10-14^{\prime} 11.27 " \mathrm{~W}\right)$, located at the southern end of the city, is $15 \mathrm{~km}$ from the crude sewage discharge point and $10 \mathrm{~km}$ from S2. It is far from any source of pollution and considered a clean site.

\section{Biological material}

Assessment of metal bioaccumulation and MT level were conducted in Mediterranean mussel (Mytilus galloprovincialis). 30 individuals animals $(40$ to $60 \mathrm{~mm}$ ) were collected monthly in 
Vol. 06, No. 03; 2021

ISSN: $2456-8643$

each sites andwashed in fresh seawaterin order to free any impurities then they are placed in cooler containing seawater from sampling site. In the laboratory, animals were kept in confinement for 48 hours to remove the contents of the digestive tract and frozen at $-30^{\circ} \mathrm{C}$ until their use for the mineralization step or for MT extraction.

\section{Metals bioaccumulation analysis}

For each sample, lyophilized mussel tissue aliquot $(200 \mathrm{mg})$ was placed in polyethylene pipes to which $4 \mathrm{ml}$ of pure nitric acid of analytical grade is added. They are then allowed to stand overnight at room temperature for 24 hours. After that they are placed in a heating block at a temperature of $80{ }^{\circ} \mathrm{C}$. After the tubes cooled, freshly deionized water is added (MilliQWater) to get a final volume of $50 \mathrm{ml}$. The solution thus obtained wasanalyzed by atomic absorption spectrometry (SAA) (Amiard et al., 1987).

Cadmium and nickel concentrations were determined by atomic absorption spectrometry (SAA) with Zeeman correction (SAA type VARIAN 220 Zeeman) using the UNEP/IOC/IAEA (1994) method. The device is equipped with an automatic sample smuggler (VARIAN AA 400), the atomization of the metal is done in a pyrolitic graphite furnace (Model GTA96).

For Zinc element $(\mathrm{Zn})$, copper $(\mathrm{Cu})$, the determination of concentrations was performed by atomic absorption spectrophotometry with flame (SAAF, flame: air-acetylene, Varian AA20) using the UNEP/FAO/IOC/IAEA method (1984). The correction of spectral background noise for specific wavelengths $(\mathrm{Zn}-213.9 \mathrm{~nm}, \mathrm{Cu}-324.8 \mathrm{~nm}$ ) is done with a deuterium lamp.

Quality control was applied to all metal analyses. A standard white and two certified materials (IAEA-407/IAEA-437 and IAEA-405/IAEA-433) of known concentration are included in the analytical series in systematic manner. Reference materials are essential tools available to laboratories to monitor and evaluate the performance of their chemical testing procedures. Control samples are processed under the same analytical conditions as the samples to be analyzed.

\section{Metallothionein analysis}

Mussels collected at each site were used for MT determination. They were weighed (total weight), then the soft tissues were separated from the shell and drained with absorbent paper, and then dissected in order to recover branchias and digestive gland of each individual. These tissues are cold-crushed in three volumes of a lysis solution consisting of a Tris- $\mathrm{HCl} 20 \mathrm{mM}$ tampon; $\mathrm{pH}$ 8.6; sucrose $0.5 \mathrm{M}$; PMSF $0.5 \mathrm{M} ; 0.01 \mathrm{mM} \beta$-mercaptoethanol as a reducing agent.The subsequent homogenate is centrifuged to $30000 \mathrm{~g}$ for 20 minutes at $-4^{\circ} \mathrm{C}$.In order to precipitate the high molecular weight proteins, the resulting supernatant was treated with $1.05 \mathrm{ml}$ of cold absolute ethanol $\left(-20^{\circ} \mathrm{C}\right)$ and 801 of chloroform and underwent again a further centrifuge at 9000 $\mathrm{g}$ for 10 minutes. A volume of $40 \mu \mathrm{l}$ of $\mathrm{HCl} 37 \%, 10 \mu \mathrm{l}$ of an RNA solution $(1 \mathrm{mg} / 10 \mathrm{l})$ and three volumes of absolute cold ethanolwere added to the supernatant which was centrifuged at $9000 \mathrm{~g}$ for 10 minutes and incubated for an hour at $-20^{\circ} \mathrm{C}$. The pellet obtained and again centrifuged after washing with a solution of Ethanol/Chloroform homogenization buffer $(87: 1: 12 \mathrm{~V} / \mathrm{V})$ was then cold at $-20^{\circ} \mathrm{C}$.A final centrifugation at $9000 \mathrm{~g}$ for 10 minutes is realized.Resulting pellets containing MT were suspended in $150 \mu \mathrm{l}$ of $\mathrm{NaCl} 0.25 \mathrm{M}$ solution and $150 \mu \mathrm{l}$ a solution consisting of $\mathrm{HCl} 1 \mathrm{~N}$ containing $4 \mathrm{mM}$ of EDTA (destabilization solution). 
Metallothionein level in sample was followed by a reaction with DTNB (5.5 dithiobis 2 benzoic nitro acid) (Ellman, 1959). Sample absorbance was measured at $412 \mathrm{~nm}$ and the MT concentration was quantified using the reduced glutathione (GSH) as a reference standard(Viarengo et al., 1997) .MT concentration was expressed as $\mu \mathrm{g} / \mathrm{mg}$ of proteins of analysed tissues

The Bradford method (1976), using the Coomassie Brilliant Blue, was used for quantitative determination of proteins using bovine serum albumin as the standard.

\section{Statistical analysis}

Differences in variables investigated among sampling studied sites stations were evaluated by the analysis of variance(ANOVA). Valueswere expressed on average \pm standard deviation (SD). All statistical tests were conducted using Statistica10 (StatSoft).

\section{RESULTS}

\section{Trace metals}

The inter-site comparison of seasonal variations in trace metal content in Mytilus galloprovincialisfrom the MIR, CHIKH, STP and TZR sites is shown in Figure 2.

The temporal variations in $\mathrm{Cd}$ concentrations are different in the sites studied. In the $\mathrm{CHIKH}$ site, the Cd shows very large fluctuations with a significant increase in autumn. At STP site, these are dominated by two peaks noticeable in winter and spring. In TZR, Cd levels are generally low and not very fluctuating.

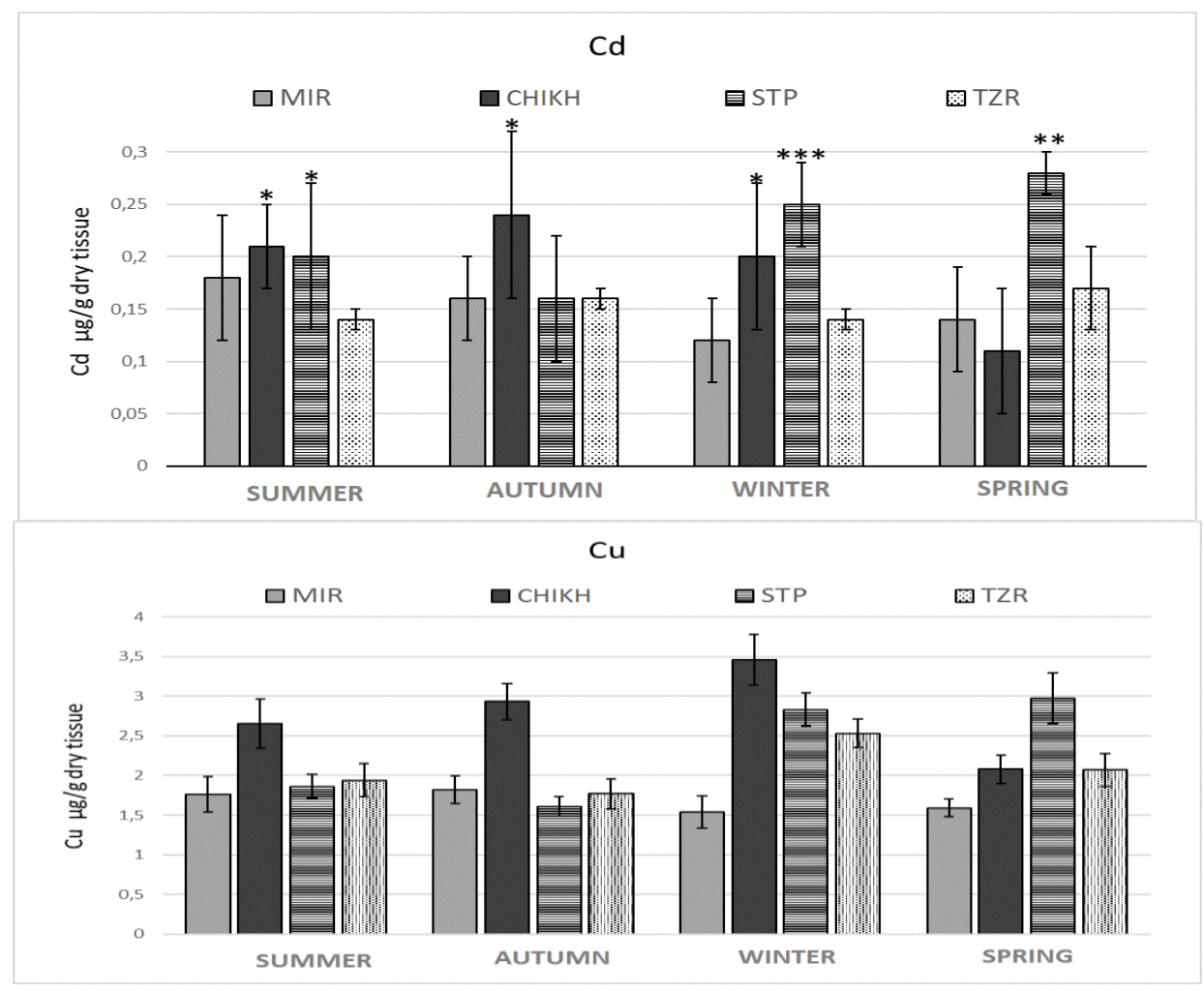




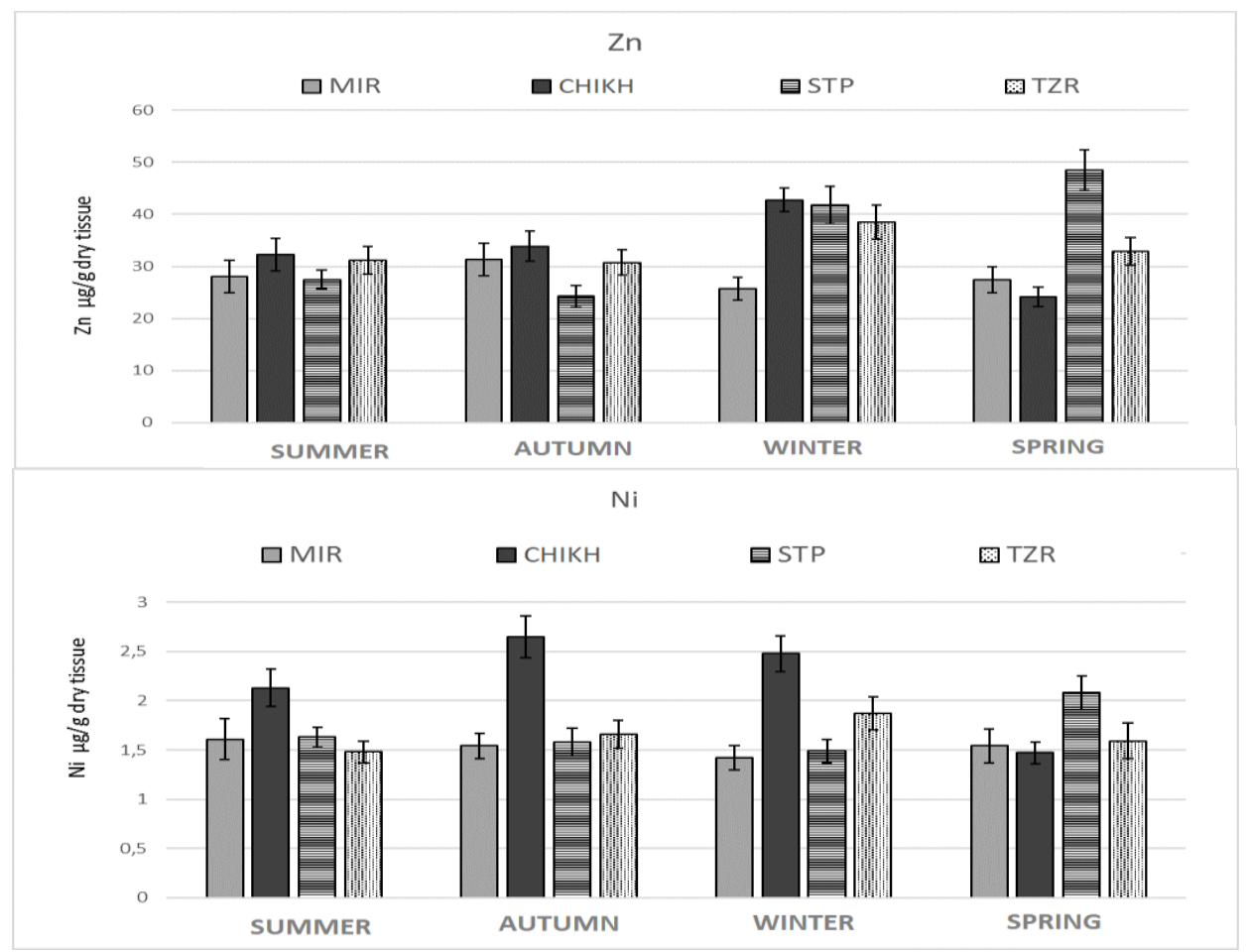

Figure 2:Seasonal variations in Cadmium $(\mathrm{Cd})$, Copper $(\mathrm{Cu})$, Zinc $(\mathrm{Zn})$ and Nickel $(\mathrm{Ni})$ bioaccumulationin Mytilus galloprovincialisatthe sites of MIR, CHIKH, STP and TZR. Significant differences from the control site (MIR): ANOVA -LSD (*, p <0.05; **, p $<0.01$; $* * *, \mathrm{p}<0.001)$

In each site, the $\mathrm{Cu}$ and $\mathrm{Zn}$ levels show the same trends. $\mathrm{Cu}$ and $\mathrm{Zn}$ show significant fluctuations with a peak in winter and a fall in the spring in site S1, while in the CHIKH site, clear seasonal variations with high concentrations in winter and autumn were obtained. However, they are almost stable in the STP site, except for a slight increase in winter.

The seasonal variations of the $\mathrm{Ni}$ are markedly different between the study sites. $\mathrm{Ni}$ concentrations at the Sheikh site fluctuate widely with well-individualized peaks in summer, autumn and winter. However, in other sites, seasonal variations are not significant if a slight increase in winter and spring concentrations is excluded, respectively at TZR and STP sites.

Compared to the control site (MIR), the highest concentrations of the four metals measured, including copper $(\mathrm{Cu})$, cadmium $(\mathrm{Cd})$, zinc $(\mathrm{Zn})$ and nickel $(\mathrm{Ni})$, were observed in mussels originating at the CHIKH station (in summer, autumn and winter; and the STP station in the spring, with highly significant differences $(* * *, p<0.001)$. However, on the TZR station, only one significant difference in $\mathrm{Cu}, \mathrm{Zn}$ and $\mathrm{Ni}$ was detected in the winter.

\section{Metallothioneins}

Figure 3 shows the evolution of the level of metallothioneins (MT) in Mytilus galloprovincialis from the MIR, CHIKH, STP and TZR sites during the period of stoppage of wastewater discharges at the CHIKH site and the start of STP. 
With the exception of spring 2014, the rate of MT accumulation is mostly higher in mussels living in Cheikh site with a maximum in winter $(13.87 \pm 2.94 \mathrm{~g} / \mathrm{mg}$ of protein).

In STP and TZR sites le level of MT shows that the seasonal variation in 2014 (winter and spring) is greater than that of 2013 (summer and autumn). The highest values (11.70 \pm 2.21 and $11.05 \pm 2.95 \mathrm{mg} / \mathrm{mg}$ of protein) are recorded in winter and spring 2014 respectively in mussels from the STP site. During this periodstudy, the rate of MT accumulation is significantly higher in mussels at this site compared to mussels at the control site.

At the TZR site, seasonal variations in metallothionein appear more in the spring and winter when the maximum level of MT induction was observed with a significantly high value (9.79 $\pm 3.07 \mathrm{~g} / \mathrm{mg}$ of protein, $\mathrm{p}<0,05)$.

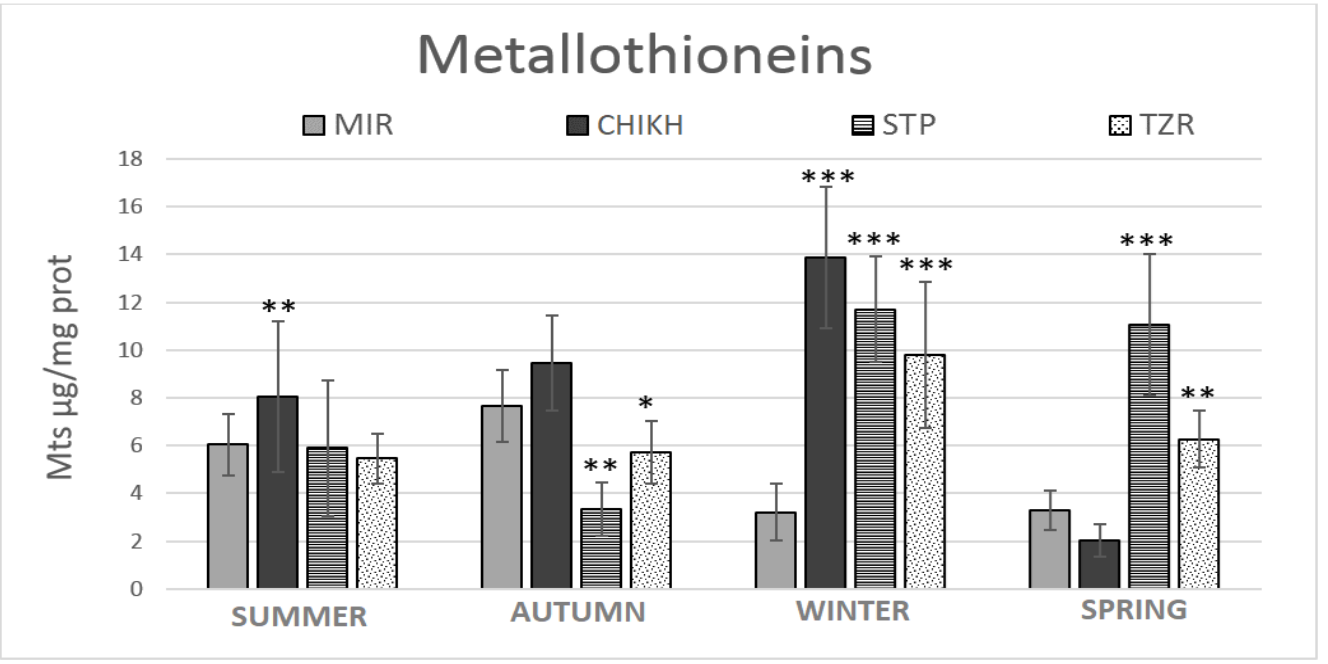

Figure 3:Evolutionof the level of metallothionein in Mytilus galloprovincialisrecoltedduring the period 2013-2014 at the sites of MIR, CHIKH,STP andTZR

Significant Difference Limit (LSD-Fisher) with the control site (MIR), *: $\mathrm{p}<0.05$; **: $\mathrm{p}<0.01$; $* * *: \mathrm{p}<0.001$

In general et comparatively to the control site (MIR), the inter-sites comparison of seasonal variations in metallothionein levels in Mytilus galloprovincialisrecoltedfrom different sites showed significantly very high winter values at all: CHIKH sites, STP and TZR ( $<<0,001)$, in the spring on the sites STP $(p<0,001)$, TZR $(p<0,01)$ and in the summer at the CHIKH site $(p<0,01)$, while a significant decrease in MT accumulation rates was recorded in the autumn on the sites STP $(\mathrm{p}<0,01)$ and TZR $(\mathrm{p}<0,05)$.

\section{DISCUSSION}

The Mediterranean mussel,Mytilus galloprovincialis, is a bioindicator widely recognized for its ability to bioaccumulate metals. This phenomenon depends on the availability of these pollutants in the biotope. Furthermore, the mussel is a species that has the ability to concentrate metals in water. 
Vol. 06, No. 03; 2021

ISSN: $2456-8643$

In the presentstudy, the assess of trace metal bioaccumulation $(\mathrm{Cd}, \mathrm{Cu}, \mathrm{Zn}$ and $\mathrm{Ni}$ ) was conducted during a seasonal cycle (summer 2013 to spring 2014) at different points of the Sidi Ifni coast.

AtCHIKHSite, most metals show high concentrations in autumn and/or winter. Indeed, several studies have described higher metal concentrations in winter than in summer in Mytilus galloprovincialis and Pernaperna(Bouthiret al., 2004;Tahiri et al., 2005; Benbrahim et al., 2006). Other authors have observed the highest levels rather in autumn (Essedaouiand Sif 2000 and 2001)in the same mussel. Variations in the results between the different authors may be related to the biology of bivalves in the study sites and especially to the quality of the biotope.

The bioaccumulation of metals in bivalves could be linked to other biological factors such as metabolism, development, age and especially the reproductive cycle. The phenomenon remains maximum before reproduction and minimal after spawning when reserves are depleted during gametogenesis(Radenac et al., 1997). This trend is confirmed by our study, which describes the highest rates of bioaccumulation in the winter before the spawning period in the spring and coinciding with the spawning period of Mytilus galloprovincialis, as described by IdHalla(1997) in Agadir Bay and Cheggour (1989) in the Bouregreg estuary.

Our study showed also that metal bioaccumulation in Mytilus galloprovincialis may have different profiles depending on the sampling site. Indeed, spatial-temporal variation in the level of metal bioaccumulation in mussels may also be related to environmental factors, such as temperature, salinity and nutrients. The winter period is often accompanied by nutrients that could lead to a rich phytoplankton potentially contaminated with trace metals from wastewater discharges and stormwater.

Cajaraville et al., 2000; Funeset al., 2006 report that trace metals can have adverse effects on aquatic organisms after they accumulate. However, not all of them have the same degree of toxicity and the same impact on the health of bivalve molluscs. Copper and zinc (essential metals) are considered harmful only after high-dose ingestion, while cadmium is harmful even at low doses (Vander Veldeet al., 1992).

SensiandJeng(2004) have demonstrated that excess zinc becomes a pro-oxidant element by inducing indirect formation of free radicals and inhibiting the enzyme activity of certain antioxidant enzymes such as reductase and peroxide glutathione (SplittgerberandTappel,1979). Other studies have shown that the accumulation of copper in the cell is the cause of cytotoxicity, which manifests itself by an enzymatic inhibition of the pyruvate-oxidase system, glucose-6phosphodeshydrogenase and glutathion-reductase are inhibited proportional to the intracellular concentration of copper(Barceloux, 1999). Therefore, the accumulation of cadmium in organisms increases the formation of reactive oxygen species and lipid peroxidation by interaction with antioxidant systems. This can cause damage to proteins, DNA and lipids(Regoliet al., 2004). It is also described as an inhibitor of DNA damage repair(Waisberg et al., 2003).

Nickel has been shown to have long-term toxic effects for aquatic invertebrates(Pane et al., 2003b),fish(Pane et al., 2003a; Banniet al., 2010) and in particular bivalves (Attiget al., 2010; Donderoet al., 2011). In addition to direct production of free radicals, this metal has been suspected of causing depletion of the antioxidant enzyme system(Denkhaus and Salnikov,2002)and is considered apro-oxidant agent. 
Vol. 06, No. 03; 2021

ISSN: $2456-8643$

Finally, it should be noted that the high rates of metal bioaccumulation recorded at the TZRsite in winter may be related to the presence of metals resulting from the degradation (corrosion) of the hull of the boat that has failed since 1994 on the beach of this site.

For metallothioneins, results of the present study responded significantly to the levels of pollution observed at sites diagnosed on the Sidi Ifni coast. These metalloproteins, which have been found in most marine animals, play a role in detoxifying by capturing metal cations of exogenous origin in the body and protecting against the effects induced by these metals(Roesijadi, 1996; Viarengoet al.,2000). Several authors have described their resence in tissues of bivalves exposed to trace metals such as $\mathrm{Cu}, \mathrm{Cd}, \mathrm{Hg}, \mathrm{Mg}$ and $\mathrm{Zn}$. However, metallothioneins are regularly considered in the literature as a parameter for assessing metal contamination(Pedersen et al.,1998; Guanand Wang, 2004; Martin-Diazet al.,2005;Amiardet al.,2006 Libergeand Bartholomew, 2007; Erket al.,2008; Wen-Honget al.,2009; Khan et al.,2010;Pytharopoulouet al.,2011; Hauser-Davis et al., 2012; Asselmanet al.,2013;Pedersenet al.,2014.Oatenet al.2015. Metallothionein induction levels has been proposed as a specific biomarker of toxic metal exposure in marine environments(Langston et al.,1998 Amiardet al.,2006) and isusually applied in international environmental biomonitoring programs (Viarengoandal.,1999 and 2007;Banniet al.,2007).

In the present study, the level of induction of MT at Cheikh site is higher than the values observed at the other sites. In addition, the induction during wastewater discharges may be due to the presence of heavy metal contamination in wastewater discharged at this site during this period. This increase in MT would certainly be related to the inflows of domestic discharges from the town of Sidi Ifni.

The heavy inductions recorded in winter and spring at the STP site are likely due to the inputs from discharges from the treatment plant specifically originating from leaching water, which coincides with the rainy season. These results lead to conclude that treated wastewater is loaded with heavy metals. Research has shown that despite improved primary and secondary wastewater treatments, discharges from the treatment plant still retain a significant amount of organic materials and metal compounds (Speir et al., 2003).

As mentioned above, with respect to the bioaccumulation of trace metals studied, the induction of MT observed in Mytilus galloprovincialis at the TZR site would be probably related to the presence of heavy metals resulting from the degradation (corrosion) of the hull of the boat stranded on this beach since 1994. Indeed, correlation between metal bioaccumulation biosynthesis of metallothionein was described in mussels and many animals in aquatic ecosystems (Fabrício el al., 2020).However, an organism's exposure to heavy metals leads to overproduction of metallothioneins accompanied by cellular damage(Cavalettoet al., 2002). However, oxidative stress alone can cause a build-up of metallothioneins in mold tissues. Significant increases in metallothionein isoforms are observed in Mytilus galloprovincialis mussels not exposed to heavy metals, but with a state of oxidative balance imbalance. (Donderoet al., 2005).

\section{CONCLUSION}

The study of the bioaccumulation of $\mathrm{Cd}, \mathrm{Cu}, \mathrm{Zn}$ and $\mathrm{Ni}$ at Mytilus galloprovincialis at the coast of Sidi Ifni, allowed to compare the process of bioaccumulation in Mediterranean mussels in different sites. This part of study allowed to confirm the polluted state of CHIKH site which 
Vol. 06, No. 03; 2021

ISSN: $2456-8643$

received, for long periods, untreated wastewater from Sidi Ifni city. These results were then reinforced by those of metallothioneins.

Our study supports the use of Mytilus galloprovincialisin environmental biomonitoring contextin marine ecosystems. The evaluation of metal bioaccumulation and metallothionein can be useful as biochemical biomarkers in marine organisms in assessing chemical exposure of different contaminants in this area.

\section{REFERENCES}

Abbassi M., Banaoui A., Kaaya A., Elkhou A., Nadir, M. and Lefrere L. (2015). Biomarker approach to the assessment of the health status of Moroccan marine ecosystems: Preliminary study in Sidi Ifni coast (South of Morocco). Journal of Materials and Environmental Sciences, Volume 6 (11) (2015) 3086-3093

Abbassi M., Banaoui A., Charioui I., Kaaya A., Elkhou A., Nadir M., Agnaou M., Lefrere L., El Hamidi F. (2017). Physico-chemical characterization of the coastal waters of the city of Sidi Ifni (Morocco). Journal of Materials and Environmental Sciences, Volume 8, Issue 9, Page 3112-3120.

Amiard J.C., Amiard-Triquet C., Berthet B. and Metayer, C. (1987). Comparative study of the patterns of bioaccumulation of essential $(\mathrm{Cu}, \mathrm{Zn})$ and non-essential $(\mathrm{Cd}, \mathrm{Pb})$ trace metals in various estuarine and coastal organisms. Journal of Experimental Marine Biology and Ecology, Vol. 106, pp. 73-89.

Amiard J. C., Amiard-Triquet C., BarkaS., Pellerin J. and Rainbow P.S. (2006). Metallothioneins in aquatic invertebrates: Their role in metal detoxification and their use as biomarkers. Aquatic Toxicology, 76, pp 160-202.

Asselman J., ShawJ. R., Stephen P. Glaholt J. K. Colbourne Karel A.C. and De Schamphelaere (2013). Transcription patterns of genes encoding four metallothionein homologs in Daphnia pulex exposed to copper and cadmium are time- and homolog-dependent. Aquatic Toxicology, Volumes 142-143, 15 October 2013, pp 422-430.

Attig H., Dagnino A., Negri A., Jebali J., Boussetta H., Viarengo A., Dondero F.and Banni M. (2010). Uptake and biochemical responses of mussels Mytilus galloprovincialisexposed to sublethal nickel concentrations. Ecotoxicology Environmental Safety. 73(7), pp 1712-1719.

Banni M., Dondero F., Jebali J., Guerbej H., Boussetta H.andViarengo A. (2007). Assessment of heavy metal contamination using real time PCR analysis of mussel metallothionein $\mathrm{mt} 10$ and mt20 expression: a validation along the Tunisian coasts. Biomarkers 12(4): pp 369-383.

Banni M., Messaoudi I., Said L., ElHeni J., Kerkeni A. and Said K.(2010). Metallothionein gene expression in liver of rats exposed to cadmium and supplemented with zinc and selenium. Arch. Environment Contamination Toxicology. 59(3), pp 513-519.

Barceloux D.G. (1999). Copper. J.Toxicol. Clin.Toxicol., 37, 2, 217-230.

Bradford MM (1976) A rapid and sensitive method for the quantification of microgram of protein utilizing the principal of protein-dye binding. Anal.Bioch., 72:248-254

Benbrahim S., Chafik A., Chfiri R., Bouthir F. Z., Siefeddine M. \&MakaouiA. (2006). Etude des facteurs influençant la répartition géographique et temporelle de la contamination des côtes atlantiques marocaines par les métaux lourds : cas du mercure, du plomb et du cadmium.Mar. Life, Vol.16 : pp 37-47. 
Bouthir F. Z., A. Chafik, S. Benbrahim, S. Souabi, H. Mardhy\& A. Messoudi, (2004). Qualité physico-chimique des eaux côtières du littoral de la Wilaya du grand Casablanca (océan Atlantique marocain) utilisant la moule Mytilusgalloprovincialis comme indicateur de la contamination métallique. Mar. Life, 14 (1-2): pp 59-70.

Cajaraville M. P., Bebianno M. J., Blasco J., Porte C., Sarasquete C. and Viarengo A., (2000). The use of biomarkers to assess the impact of pollution in coastal environments of the Iberian Peninsula: a practical approach.Sci. Tot. Environ. 247, pp 295-311.

Cavaletto M., Ghezzi A., Burlando B., Evangelisti V., Ceratto N. \&Viarengo A. (2002). Effect of hydrogen peroxide on antioxidant enzymes and metallothionein level in the digestive gland of Mytilus galloprovincialis. CompBiochem. Physiol. C, Toxicol. Pharmacol. 2002 Apr, 131(4) : pp 447-55.

Cheggour M. (1989). Bioaccumulation de quelques éléments métalliques chez un mollusque bivalveScorbiculariaplana dans l'estuaire de Bouregreg (Maroc). Bull. Ins.Sci. Rabat 13:pp 125-133.

Cheggour M., Langston W.J., Chafik A., Texier H., Kaimoussi A., Idrissi H. et Boumezzough A. (1999) Metals in the bivalve molluscsScrobicularia plana (Da Costa) and Cerastodermaedule (L.) and associated surface sédiment from Oum Er'Rbiaestuary (Moroccan Atlantic Coast). Toxicological and Environmental Chemistry, 11 49-73.

Denkhaus E. andSalnikov K., (2002). Nickel essentiality, toxicity, and carcinogenicity. Crit. Rev. Oncol. Hematol.42, pp 35-56.

Dondero F., Piacentini L., Banni M., Rebelo M., Burlando B. and Viarengo A. (2005) Quantitative PCR analysis of two molluscan metallothionein genes unveils differential expression and regulation. Gene 345: pp 259-270.

Dondero F., Banni M., Negri A., Boatti L., Dagnino A. and Viarengo A. (2011). Interactions of a pesticide/heavy metal mixture in marine bivalves: a transcriptomic assessment. BMC Genomics12,195 pages.

Eddaoudi R., Chafik A., Cheggour A. and Moukrim A. (2014). Contribution to reassess the health of Agadir Bay after the installation of the wastewater treatment plant: evaluation of metallic contamination. Journal of Materials and Environmental Sciences 5 (S1), pp 22782283

El Hraiki A., Kessabi M., Sabhi Y., Benard P. et Buhler D. R. (1992). Contamination par le cadmium, le chrome, le mercure et le plomb des produits de la pêche marocaine prélevés en mer Méditerranée. Revue Med. Vet., 1992, 143, 1,49 - 56.

Ellman GL (1959). Tissue sulfhydryl groups. Arch. Bioch. Biophys. 82, pp 70-77.

Erk M., Muyssen B.T.A., Ghekiere A. A, Janssen C.R. (2008). Metallothionein and cellular energy allocation in the estuarine mysid shrimp Neomysis integer exposed to cadmium at different salinities. J. Exp. Mar. Biol. Ecol., 357, pp 172-180.

Essedaoui A. \&Sif J. (2000). Variation des activités estérasiques sous l'effet de la pollution métallique chez Mytilusgalloprovincialis de la région de Jorf-Lasfar (Maroc).J. Rech. Océanogr., 25, 3/4, pp 34-42.

Essedaoui A.\&Sif J. (2001). Bioaccumulation des métaux lourds et induction des métalloprotéines au niveau de la glande digestive deMytilusgalloprovincialis. Actes Inst. Agron. Vet. (Maroc), Vol. 21, (1) : pp 17-25.

Fabrício Â. G., Hauser-Davis R. A., Soares L., MazzucoA. C. A., Chavez Rocha R. C., Saint 
Pierre T. D., Saggioro E., Verissimo Correia F., Ferreira T. O. and Bernardino A. F. (2020). Contamination and oxidative stress biomarkers in estuarine fish following a mine tailing disaster. Peer J., 01-25.

Funes V., Alhama J., Navas J. I., Lopez-Barea J. and Peinado J. (2006). Ecotoxicological effects of metal pollution in two mollusk species from the Spanish South Atlantic littoral. Environ. Pollut. 139: pp 214-23.

Guan R.and Wang W.X. (2004). Cd and Zn uptake kinetics in Daphnia magna in relation to Cd exposure history. Envir. Sc. Tech., 38, pp 6051-6058.

Hauser-Davis R. A., Gonçalves R. A., Ziolli R. L. and De Campos R. C. (2012).A novel report of metallothioneins in fish bile: SDS-PAGE analysis, spectrophotometry quantification and metal speciation characterization by liquid chromatography coupled to ICP-MS. Aqua. Toxicol., Volumes 116-117, 15 July 2012, pp 54-60.

Hazrat A.,Ezzat K. and Ikram I. (2019). Environmental Chemistry and Ecotoxicology of Hazardous Heavy Metals: Environmental Persistence, Toxicity, and Bioaccumulation. Journal of Chemistry, Review article, Vol 2019, ID6730305, https://doi.org/10.1155/2019/6730305.

IdHalla, M. (1997). Etude de la biologie des moulesPernapernaLinné (1758) et MytilusgalloprovincialisLamarck (1819) dans la baie d'Agadir.Diplôme des Etudes Supérieures, Université. Ibn Zohr, Faculté des Sciences, Agadir., 157 pages.

Kaimoussi A., Chafik A., Mouzdahir A. and Bakkas S. (2001). The impact of industrial pollution on the JorfLasfar coastal zone (Morocco, Atlantic ocean) :The mussel as an indicator of metal contamination. Compte Rendu de l'Académie des Sciences de Paris, 333, 337-341.

Kaaya A. (2002). Contribution à l'évaluation de l'état de santé de la baie d'Agadir : étude de la physico-chimie du milieu et de certains biomarqueurs chez Mytilusgalloprovincialis et Pernaperna (stratégie de réserve, bioaccumulation métallique et enzymes de biotransformation). Thèse Doctorat d'État, Université. Ibn Zohr, Faculté des Sciences, Agadir, 485 pages.

Khan F.R., Bury N.R.andHogstrandC., (2010). Cadmium bound to metal rich granules and exoskeleton from Gammarus pulex causes increased gut lipid peroxidation in zebrafish following single dietary exposure.Aqu. Toxicol. 96, pp 124-129.

Langston W. J., M. J. Bebiano and G. R Burt. (1998). Metal handling strategies in molluscs: Metal Metabolism in aquatic environments. Chapman \& Hall, London, U. K. pp 219-283.

LibergeM.andBarthélémy R.M. (2007).Localization of metallothionein, heat shock protein (Hsp70), and superoxide dismutase expression in Hemidiaptomusroubaui (Copepoda, Crustacea) exposed to cadmium and heat stress. Can. J. Zool., 85, pp 362- 371.

Lower W.R. and Kendall R. J. (1990). Sentinel species and sentinel bioassay. In: Mc Carthy J. F.; Shugart L. R. (eds), Biomarkers of Environnemental Contamination. Lewis publishers, Boca Raton. pp 309-331.

Martin-Diaz M.L., Villena-Lincoln A., Bamber S., Blasco J.andDelvalls T.A. (2005). An integrated approach using bioaccumulation and biomarker measurements in female shore crab, Carcinusmaenas. Chemosphere 58, pp 615-626.

Oaten J.F.P., HudsonM.D., JensenA.C.andWilliams I.D. (2015). Effects of organism preparation in metallothionein and metal analysis in marine invertebrates for biomonitoring marine pollution. Sci. Tot. Environ., Volumes 518-519, 15 June 2015, pp 238-247.

Pane E.F., Richards J.G. and Wood C.M. (2003a). Acute waterborne nickel toxicity in the 
Vol. 06, No. 03; 2021

ISSN: $2456-8643$

rainbow trout (Oncorhynchus mykiss) occurs by a respiratory rather than ionoregulatory mechanism. Aquat. Toxicol. 63: pp 65-82.

Pane E.F., Smith C., McGeer J.C. and Wood C.M. (2003b). Mechanisms of acute and chronic waterborne nickel toxicity in the freshwater cladoceran, Daphnia magna. Environ. Sci. Technol. 37: pp 4382-4389.

Pedersen S. N., Pedersen K. L., HojrupP., Knudsen J. and Depledge M. H. (1998) Induction and identification of Cadmium, Zinc and Copper-metallothioneinsin the shore crab Carcinusmaenas (L.). Comp BiochemPhysiol C PharmacolToxicolEndocrinol. 120, pp 251259.

PedersenKnudLadegaard, LouiseThornhoj Bach andPoulBjerregaard (2014). Amount and metal composition of midgut gland metallothionein in shore crabs (Carcinusmaenas) after exposure to cadmium in the food. Aqu. Toxicol., Volume 150, May 2014, pp 182-188.

Pytharopoulou Sofia, KonstantinosGrintzalis, EleniSazakli, MichelLeotsinidis, Christos D. Georgiou and Dimitrios L. Kalpaxis (2011).Transnational responses and oxidative stress of mussels experimentally exposed to $\mathrm{Hg}, \mathrm{Cu}$ and $\mathrm{Cd}$ : One pattern does not fit at all. Aqua. Toxicol., Volume 105, Issues 1-2, September 2011, pp 157-165.

Radenac G, Miramand P and Tardy J. (1997). Search for impact a dredged material disposal site on growth and metal contaminationof Mytilus edulis ( $L$.) in Charente Maritime (France).Mar. Pollut. Bull. 34: pp 721-729.

RegoliF., Frenzilli G., BocchettiR., Annarumma F., Scarcelli V., Fattorini D.and Nigro M., (2004). Time-course variations of oxyradical metabolism, DNA integrity and lysosomal stability in mussels, Mytilus galloprovincialis, during a field translocation experiment. Aquat. Toxicol. 68, pp 167-178.

RoesijadiG. (1996). Metallothionein and its role in toxic metal regulation. Comp. Biochem. Physiol. C Pharmacol. Toxicol. Endocrinol. 113, pp 117-123.

Sensi S. L. and Jeng JM (2004). Rethinking the excitotoxic ionic milieu: the emerging role of $\mathrm{Zn}$ (2+) in ischemic neuronal injury. Curr. Mol. Med., 4: pp 87-111.

Speir T. W., Van Schaik, A.P., Percival, H.J., Close, M.E.andPang L. (2003). Heavy metals in soil, plant and groundwater following high-rate sewage sludge application to land.Water Air Soil Pollut. 150, pp 319-358.

Splittgerber A. G. andTappel A. L. (1979). Steady state and pre-steady state kinetic properties of rat liver selenium-glutathione peroxidase. J. Biol. Chem., V. 254, n. 19, pp 9807-9813.

Tahiri L., Bennasser L., Idrissi L., Fekhaoui M., El Abidi A. \&Mouradi A. (2005). Contamination métallique de Mytilusgalloprovincialis et des sédiments au niveau de l'estuaire de Bouregreg (Maroc). Water Qual. Res. J. Canada, Volume 40, No. 1, pp 111-119.

UNEP/FAO/IOC/IAEA (1984): Determination of total cadmium, zinc, lead and copper in selected marine organisms by flameless atomic absorption spectrophotometry. Reference Methods for Marine Pollution Studies No. 11. UNEP, 1984, 18 pages.

UNEP/IOC/IAEA (1994): Determination of organotins in environmental samples.Reference Methods for Marine Pollution and Studies No. 59. UNEP, 1994, 38 pages.

Van Der Velde G., Hermus K., van der Gaag M. and Jenner H., (1992). Cadmium, Zinc and Copper in the body, byssus and shell of the mussels,Mytilopsisleucophaeta and Dreissenapolymorphain the brackish noordzeekanaal of the Netherlands. LimnologieAktuell, 2: pp 213-226. 
Viarengo A., PonzanoE., Dondero F., \&FabbriR. (1997). Simple methods for metallothionein evaluation in the tissues of marine invertebrates such as Mediterranean and Antarctic Molluscs. Mar. Environ. Res., 44, pp 69-84.

Viarengo A., Burlando B., Cavaletto M., Marchi B., Ponzano E., Blasco J. (1999). Role of metallothionein against oxidative stress in the mussel Mytilus galloprovicialis. Am. J. Physiol. Regul. Integ Comp Physiol, 277, R1612-R1619.

Viarengo A., Burlando B., Ceratto N. andPanfoli I. (2000). Antioxidant role of metallothioneins: a comparative overview. Cell. Mol. Biol. 46: pp 407-417.

Viarengo A., Lowe D., Bolognesi C., Fabbri E. and Koehler A. (2007). The use of biomarkers in biomonitoring: a 2-tier approach assessing the level of pollutant-induced stress syndrome in sentinel organisms.Comp. Biochem. Phydiol. C146, pp 281-300.

WaisbergM., Joseph P. and Hale B. and Beyersmann, D. (2003). Molecular and cellular mechanisms of cadmium carcinogenesis. Toxicology 192: pp 95-117.

Wen-Hong F., Tang G., Zhao C.M., Duan Y.and Zhang R., (2009). Metal accumulation and biomarker responses in Daphnia magna following cadmium and zinc exposure. Environ. Toxicol. Chem., 28, pp 305-310. 